\title{
Awareness and Use of Free/ Open Software for Science and Mathematics Education
}

\author{
Vandna Luthra ${ }^{1}$, Arshmeet Kaur², Sunanda Saini ${ }^{3}$, D. Ahuja ${ }^{3}$, A. Nagpal ${ }^{3}$, M.Pal ${ }^{1}$, \\ M. Uniyal ${ }^{1}$, A. Bharadwaj ${ }^{1}$ \\ ${ }^{1}$ Department of Physics, Gargi College, Siri Fort Road, New Delhi-110049, India. \\ ${ }^{2}$ Department of Mathematics, Gargi College, Siri Fort Road, New Delhi-110049, India \\ ${ }^{3}$ Department of B.El.Ed, Gargi College, Siri Fort Road, New Delhi-110049, India
}

\begin{abstract}
Teaching and learning are best thought of not as separate and independent activities, but rather as two sides of the same coin interconnected and interrelated. In the new technology era, the role of teacher has changed and continues to change from being an instructor to a constructor, facilitator, coach and creator of learning situations. In facilitating \& creating learning situations many open and paid resources help the teachers. In present paper results were presented from a study conducted on school teachers regarding use of open and paid resources/software. Results were discussed in context of use of processing \& content specific software (free \& Open Vs. Paid). The study also aimed at getting status of usage and comparison of various software for Science and Mathematics education. The Implications of this study would help and promote planning of future workshops to enhance the use of digital resources/software.
\end{abstract}

\section{CONCEPTUAL FrameWORK}

Use of open and paid resources/software has become an integral part of today's teaching - learning process. There is a surge in the usage of various software for education worldwide. These provide effective ways of disseminating and communicating information in all areas of education. In present day education, an updated teaching would depend on how well the teachers are equipped with technical resources. Since these resources are powerful tools for problem-solving, conceptual development and critical thinking thereby aiding to make the learning process much easier for the students.

School education can become better through quality education that can be nurtured through enriching teaching - learning process. The demands of the 21 st century information rich and knowledge based society, makes it essential for both teachers and students to utilize technology effectively. Within a sound educational setting, technology can empower and enable students to become capable analyzers, and evaluators.

\section{Importance of Open and Paid Resources/software in Classroom Teaching- Learning Process}

Open and Paid resources/software play an important role in the classroom teaching-learning process as discussed below:

- Use of software encourages contact between students and teachers, especially those students who are unwilling to speak out in face-to-face classroom settings.

- For the benefits of peer learning use of software develop reciprocity and cooperation among students.

- Active learning techniques can be involved by using software that help students to learner through visual representation of abstract concepts in mathematics and sciences.

- With the help of software necessary prompt feedback can be provided.

- Diverse talents and ways of learning explored by use of software.

- Both teaching and learning efficiency improved by use of software. 
- Students can learn according to their own pace with flexibility and rich medium of information by use of open and paid resources/software.

- Learning, retention and student performance become better due to multi-sensory learning experiences.

- Digital resources can help teachers have access to colleagues, institutions, universities, centre of expertise, rich resources and cyber space and national organization involved in education and research.

- Development of effective teaching tools and designing of the modules become possible to promote interdisciplinary approach which in turn helps the teacher to become multi-facilitators.

\section{BASIC REQUIREMENTS FOR USING VARIOUS SOFTWARE FOR EDUCATION}

Here it is pertinent to note that to effectively harness the power of the new free/open and paid software for improving teaching and learning, the following essential conditions must be met:

- Sufficient access to digital technologies and the Internet in classrooms and schools must be there for teachers.

- High quality, meaningful, and culturally responsive digital content must be available for teachers.

- Teachers must have the knowledge and skills to use the new digital tools and resources to help all students achieve high academic standards.

In changing scenario, the role and function of a teacher is changing. Now the emphasis is on the selflearning under the guidance of a teacher, who is a facilitator to introduce student with new technologies. To obtain excellence in every aspect of the teaching-learning process, teachers should be ready to use open and paid resources/software for overall development of their students like cognitive, affective and psychomotor development.

\section{OBJECTIVES OF THE STUDY}

- To study the awareness of open/free and content specific software among school teachers

- To get an overview of planning to use open/free software in future in their classroom by school teachers

- To compare the use of paid and open/free software by school teachers.

- To compare the use of basic processing software and content specific software for Mathematics \& Sciences by school teachers.

- To study the effectiveness of usage of ICT in enhancing teaching learning process.

\section{Method And Procedure}

For the present study descriptive survey method is used. For collecting data, responses from teachers were taken through a questionnaire selected randomly from government/aided/private schools.

\section{ReSUlts}

After collecting data considering the objectives of the study analysis and interpretation was covered under subsequent sections by using percentage.

\subsection{An Overview of Awareness of Open/Free and Content Specific Software Among School Teachers}

After analyzing responses, $51 \%$ of the respondents say that they are aware of open/free and content specific software. Out of these $26 \%$ of the respondents say that they are aware about open resources and $25 \%$ say they are also aware about content specific software. 


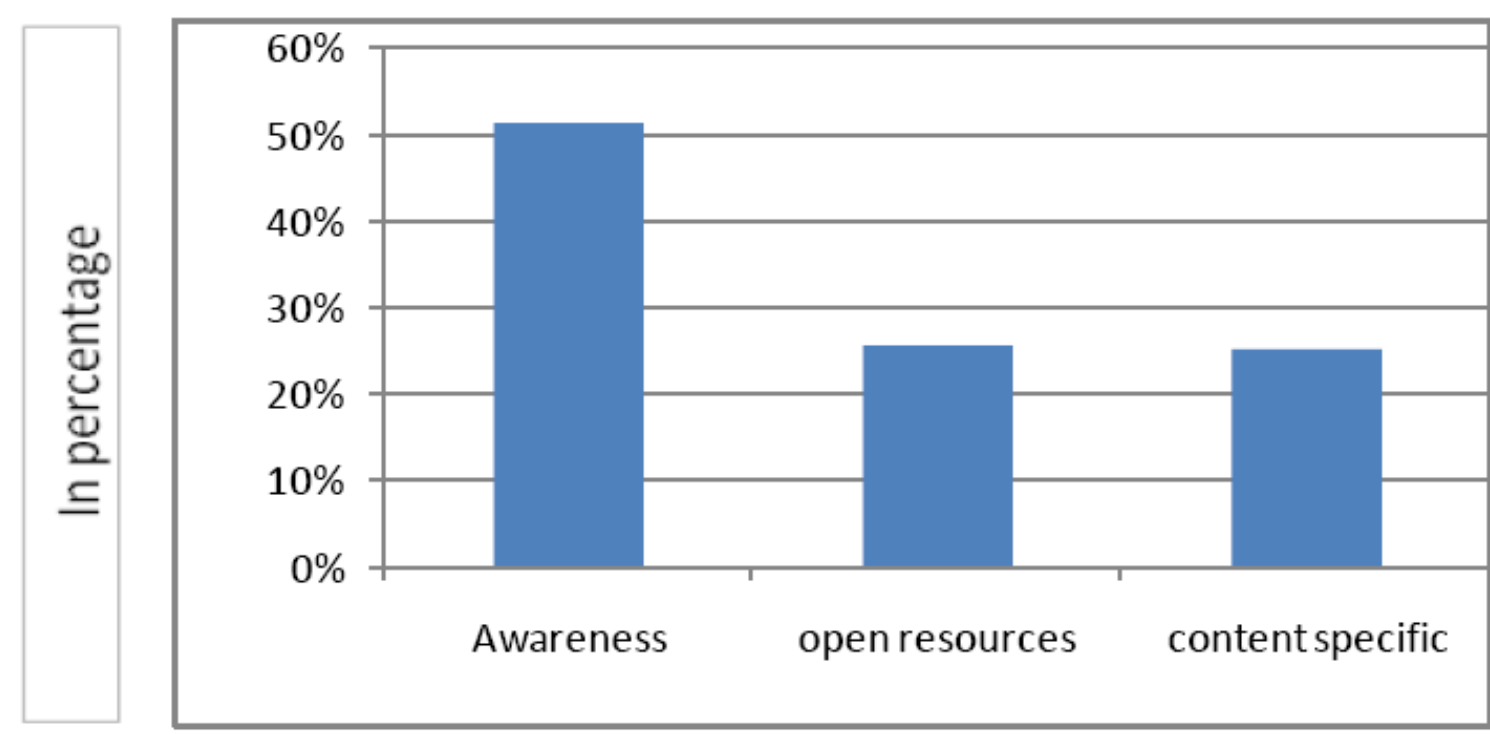

Govt. /Aided/Private School teachers

6.2. An Overview of Planning to Use Open/Free Software in Future in Their Classroom by School Teachers

Data collected from school teachers when analyzed, shows that more than three fourth of the respondents are planning to use open/free software in future in their classroom.

\subsection{Comparison of Use of Paid and Open/Free Software by School Teachers}

Out of total respondents $75 \%$ are not using/incorporating software in their teaching and learning. From rest of the $25 \%$, those who are incorporating software $78 \%$ are using paid software and rest $22 \%$ are using open/free software.

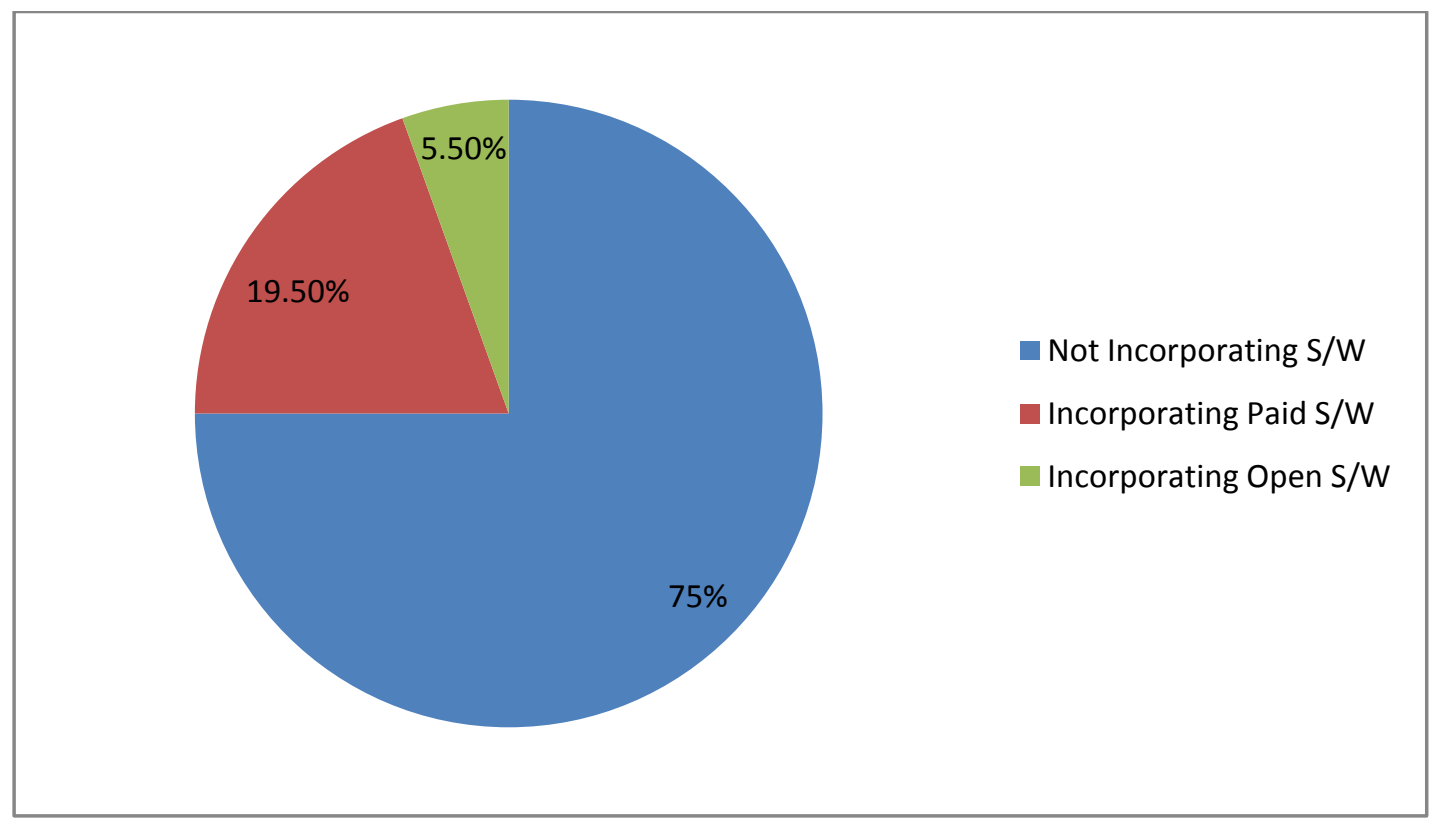

6.4. Comparison of Use of Basic Processing Software and Content Specific Software for Mathematics \& Sciences by School Teachers

As analyzed above $25 \%$ are using software out of these $40 \%$ are using content specific software in mathematics and $60 \%$ using basic processing software. In case of sciences $20 \%$ are using content specific and rest of the $80 \%$ using basic processing software. 


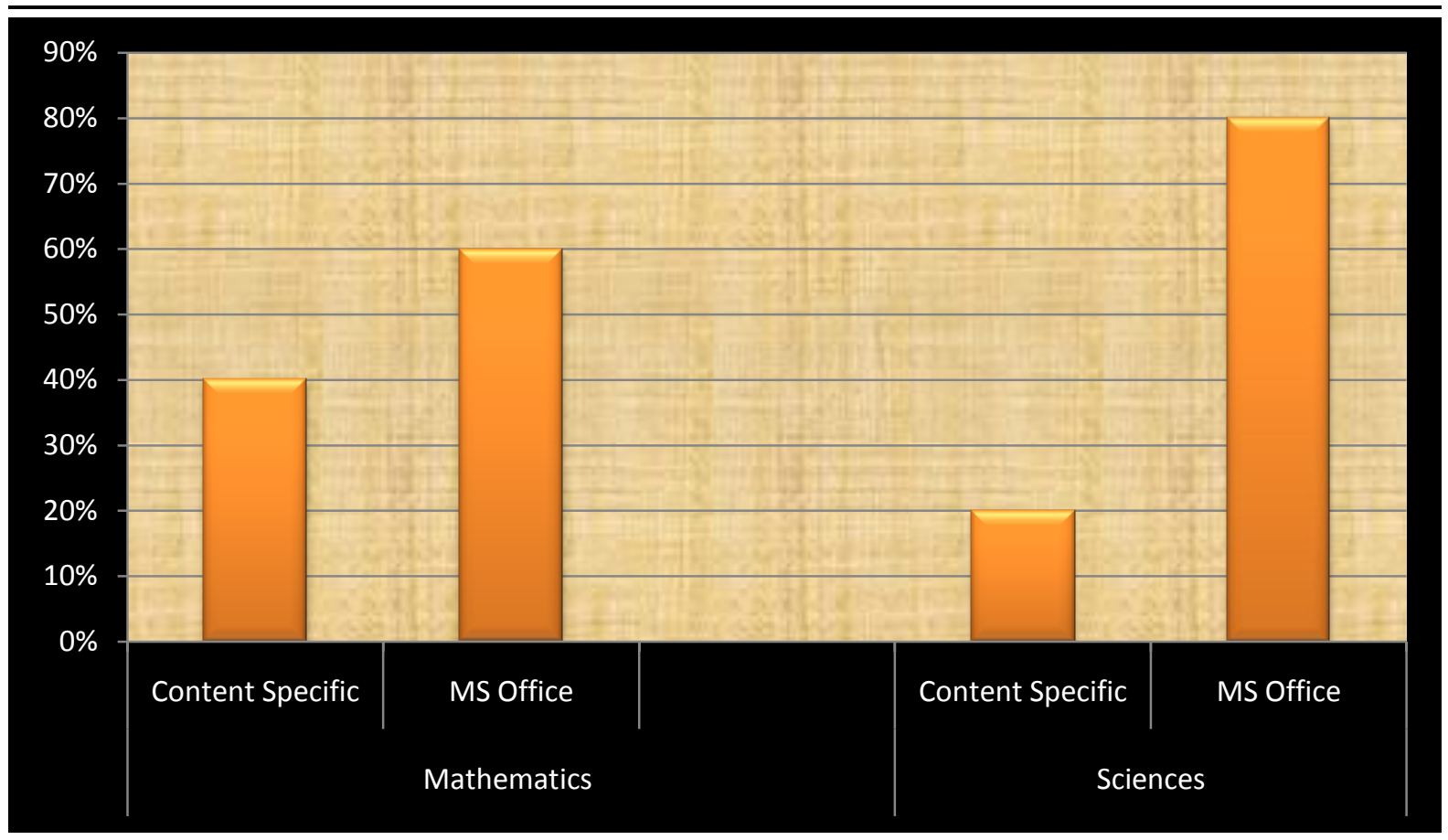

\subsection{Use of ICT is Effective in Enhancing Teaching Learning Process}

After analyzing the responses $99 \%$ of the respondents were of the opinion that usage of ICT is effective in enhancing teaching learning process.

\section{Conclusion}

While concluding we can say that school teachers are aware about open/free and paid software. It is clear from the result that majority of them are not using/incorporating software in their teaching even though they are also agreeing upon the statement that ICT is effective in enhancing teaching learning process. So, this may be the reason they are planning to use software in future in their classroom. We feel that organising more workshops/training programmes can help in promoting and encouraging school teachers in incorporating at least open/free software in teaching learning process.

\section{ACKNOWLEDGEMENT}

The authors are thankful to GC 301 Innovation Project grant (DU) to Gargi College. The authors are also thankful to Dr. Ajith B.P (IUAC) for useful discussions.

\section{REFERENCES}

Baskin, C., \& Williams, M. (2006). ICT integration in schools: Where are we now and what comes next? Australasian Journal of Educational Technology, 22(4), 455-473. Retrieved from ttp://www.ascilite.org.au/ajet/ajet22/baskin.html

Becta, (2004). A review of the research literature on barriers to the uptake of ICT by teachers. British Educational Communications and Technology Agency. Retrieved from http://www.becta.org.uk /page_documents/research/barriers.pdf

Ceccheni, S., \& Raina, M. (2002). "Warana: The Case of an Indian Rural Community Adopting ICT". Information Technology in Developing Countries, 12(1). Retrieved from <http://www. iimahd.ernet.in/egov/ifip/apr2002/article3.htm>.

Dupagne, M.., \& Krendi, K. (1992). Teachers' attitudes toward computers. A Review of the Literature. Journal of Research on Computing in Education, Spring 92. 24(3): 420-429.

Hennessy, S., Ruthven, K., \& Brindley, S. (2005). Teacher perspectives on integrating ICT into subject teaching: commitment, constraints, caution, and change. Journal of Curriculum Studies, 37 (2), 155-192.

Newa, D. (2007). Teacher effectiveness in relation to work satisfaction, media utilization and attitude towards the use of information and communication technology among secondary school teachers of Nepal. (Doctoral dissertation). Retrieved from www.pu.ac.in. 
Prasad, S. N. (2005). Survey Report on Pre-service Teacher Training on ICT Use in Education in Asia and the Pacific India: A Case Study, Retrieved from http://www.unescobkk.org/fileadmin/ user_upload/ict/Misc/TT_India.pdf

Risah, J., Suluan, \& Roslan, S. (2005). In-service teachers' views towards technology and teaching and their perceived competence towards information technology. Technology Journal,43(E):114. Retrieved from http://www.penerbit.utm.my/onlinejournal/43/E/JTDIS43E1.pdf

Sansanwal, D.N. (2000). Information Technology and Higher Education. University News, 38, 46.

Singh, Y.P., \& Agarwal, A. (2010). ICT- integration in teacher education: point of strength \& weakness. Teacher Education Journal, 44(1-2), 102-110.

United Nations Educational, Scientific and Cultural Organization (2008). UNESCO ICT Competency Standards for Teachers, 7, place de Fontenoy, Composed and printed in the workshops of METIA. Retrieved from http://cst.unesco-ci.org/sites/projects/cst/default.aspx 